\title{
Serum Fetuin-A Level is Not Correlated with Subclinical Atherosclerosis in Patients with Amyloid A Amyloidosis
}

\section{Amyloid A Amiloidozlu Hastalarda Serum Fetuin-A Seviyesi Subklinik Ateroskleroz ile İlișkili Değildir}

\author{
(D) Ali Bakan, (1) Sebahat Alışır Ecder \\ İstanbul Medeniyet University, Göztepe Training and Research Hospital, Clinic of Nephrology İstanbul, Turkey
}

\section{ABSTRACT}

Objective: Amyloidosis is the build-up of amyloid fibrils in tissues, which eventually leads to various local and systemic problems. Amyloid A amyloidosis (AA amyloidosis) is the most frequent type of systemic amyloidoses. Data from cohort studies show that decreased serum fetuin-A (SF-A) levels in the serum are associated with morbidity and mortality in patients with end-stage kidney disease. Our aim was to investigate whether elevated SF-A levels were associated with common carotid intima-media thickness (IMT) in patients with AA amyloidosis.

Methods: We recruited 63 patients with AA amyloidosis and 29 age-matched healthy controls. Demographic data, biochemical parameters, SF-A and carotid IMT values between two groups were compared. We also investigated the association between carotid IMT and SF-A levels in patients with AA amyloidosis.

Results: We determined a significant increase in carotid IMT among patients with AA amyloidosis compared to healthy controls $(p<0.001)$. SF-A levels were similar in patients and controls ( $p=0.11)$. In addition, we did not find any correlation between SF-A levels and carotid IMT ( $r=0.074, p=0.565)$.

Conclusion: Our study showed that SF-A levels were not changed in patients with AA amyloidosis. Also, SF-A levels and carotid IMT were not associated in patients with AA amyloidosis.

Keywords: AA amyloidosis, carotid intima-media thickness, fetuin-A

öz

Amaç: Amiloidoz amyloid fibrillerin dokularda birikmesi ile olușur, çeșitli lokal ve sistemik semptomların olușmasına neden olur. Amyloid A amyloidozis (AA amyloidozis) sistemik amiyloidozun en sık görülen tipidir. Çalıșmalar, azalmış serum fetuin-A (SF-A) seviyesi son dönem böbrek hastalarında artmış morbitite ve mortaliteyle birlikte olduğunu göstermiş̧tir. Amacımız AA amiloidozlu hastalarda yüksek SF-A düzeylerinin ortak karotis intima-media kalınlığı (IMT) ile ilişkili olup olmadığını araștırmaktı.

Yöntemler: Çalıșmaya 63 AA amiloidozlu olgu ve 29 sağlıkı kontrol dahil ettik. İki grubun demografik verilerini, biyokimasal parametrelerini, SF-A seviyelerini ve karotis IMT değerlerini karșılaștırdık. Aynı zamanda AA amiloidozlu hastalarda karotis intima-media kalınlığı ile SF-A düzeyleri arasındaki ilișkiyi araștırdık.

Bulgular: Kontrol grubu ile karşılaștırıldığında AA amiloidozlu hastalarda karotis IMT'nin anlamlı derecede artığını tespit ettik(p<0,001). Kontrol grubu ile hasta grubu arasındaki SF-A seviyeleri benzerdi ( $p=0,11)$. Karotis IMT ile SF-A düzeyi arasında herhangi bir korelasyon yoktu( $r=0,074, p=0,565)$.

Sonuç: Çalıșmamızda AA amiloidozlu hastaların SF-A seviyesinde değișiklik yoktu. Aynı zamanda karotis intima-media kalınlığı ile SF-A düzeyi arasında herhangi bir korelasyon yoktu.

Anahtar Kelimeler: AA amiloidozis, karotis intima-media kalınlığı, fetuin A

Received/Geliș tarihi: 06.04.2019 | Accepted/Kabul tarihi 19.06.2019

Address for Correspondence/Yazıșma Adresi: Ali Bakan, İstanbul Medeniyet University, Göztepe Training and Research Hospital, Clinic of Nephrology İstanbul, Turkey

Phone/Telefon: +90 5326344548 E-mail/E-posta:dralibakan@yahoo.com.tr ORCID-ID: orcid.org/0000-0002-6192-0973

Atıf/Citation: Bakan A, Alșır Ecder S. Serum Fetuin-A Level is Not Correlated with Subclinical Atherosclerosis in Patients with Amyloid A Amyloidosis. Bakırköy Tıp Dergisi 2019;15:280-6 https:// 10.4274/BTDMJB.galenos.2019.20190406062918 


\section{INTRODUCTION}

Amyloidosis is characterized by the accumulation of abnormal fibril proteins which leads various local and systemic diseases. The amyloid fibrils are usually comprised of mutant, fragmented and altered proteins with abnormal conformation.

On the global scale, amyloid A (AA) amyloidosis is reportedly the most frequently diagnosed form of amyloidosis. It is especially frequent in the developing countries, which is considered to be due to higher frequency of associated infections. Proteinuria and/or impaired renal function, which may progress to chronic renal failure, is known to develop in patients with AA amyloidosis (1). In patients with end-stage renal disease, arterial stiffness has been reported to be independently associated with all-cause cardiovascular mortality and morbidity $(2,3)$. Clinical and subclinical atherosclerosis can be evaluated by the measurement of common carotid intima-media thickness (IMT) (2,4-6).

Human serum fetuin-A (SF-A) (also known as alpha-2 Heremans-Schmid glycoprotein) is an endogenous blood glycoprotein with inhibitory effects on cysteine proteases. It is secreted from the liver and has a role in systemic calcification. SF-A also functions in various metabolic pathways, including calcium homeostasis/bone development, phagocytosis and is suggested to contribute to insulin sensitivity (7-9). Some recent studies have demonstrated inverse relationships between SF-A levels and atherosclerosis $(7,9,10)$. Several cohort studies focused on patients with end-stage renal disease have concluded that lower SF-A levels are associated with mortality and cardiovascular events (11).

To our knowledge, there are only a few studies that have investigated carotid IMT in patients with AA amyloidosis. Furthermore, we found no studies that investigated SF-A levels and carotid IMT in AA amyloidosis.

Our aim was to evaluate whether any relationship existed between subclinical atherosclerosis (carotid IMT) and SF-A levels in patients with AA amyloidosis.

\section{METHOD}

This study was performed on 63 patients with AA amyloidosis who attended their usual follow up studies between April 2018 and May 2018 at the Nephrology Department of Internal Diseases. The control group was comprised of 29 aged-matched healthy subjects. The investigation was performed as an observational crosssectional study. AA amyloidosis was diagnosed by means of biopsies from different tissues such as the kidney, gingiva, rectum, duodenum or bone marrow. Patients with diabetes mellitus, hypertension, liver diseases, hyperthyroidism, hypothyroidism, hematological disorders, malignancy and acute/chronic infections were excluded from the study.

Patients' systolic and diastolic blood pressures (SBP and DBP, respectively) were measured with a sphygmomanometer while the patient was sitting after at least 5 minutes of rest. Body mass index (BMI) was calculated by dividing weight $(\mathrm{kg})$ by the square of height $\left(\mathrm{m}^{2}\right)$. The Chronic Kidney Disease Epidemiology Collaboration equations was used to calculate estimated glomerular filtration rate (eGFR) (12).

Plasma samples were aliquoted and stored at $-80{ }^{\circ} \mathrm{C}$ until measurement. SF-A levels were measured with a human fetuin enzyme-linked immunosorbent assay kit (BioVendor Laboratory Medicine, Czech Republic) according to manufacturer instructions. Erythrocyte sedimentation rate (ESR), urea, creatinine, albumin, calcium, phosphate, C-reactive protein (CRP) and parathyroid hormone (PTH) levels were measured by the routine biochemistry laboratory via auto-analyzers.

\section{Measurement of Carotid Intima-Media Thickness}

Measurements of carotid IMT were performed with a 5-12 $\mathrm{MHz}$ superficial probe using an M-Turbo ultrasonography device (SonoSite Inc., Bothell, WA, USA). The carotid IMTs were measured from the classic site described by Pignoli et al. (13) (1 cm proximal to the bifurcation). The carotid IMT was defined as the distance between the media-adventitia and the lumen-intima interfaces. The final carotid IMT values of each patient was calculated as the mean of triplicate measurements of both carotid arteries.

The study was approved by İstanbul Medeniyet University Göztepe Training and Research Hospital Clinical Research Ethics Committee on April 10, 2018 (Protocol number: 2013-KAEK-64), and informed consents were taken from all participants.

\section{Statistical Analysis}

All data analysis was performed on Statistical Package for Social Sciences (SPSS) version 21.0 program for the Windows operating system (SPSS Inc., Chicago, USA). The normality of distribution of continuous variables 
were evaluated with the Shapiro-Wilk test. We analyzed descriptive statistics (medians and standard deviations) and performed 2-group comparisons with the students t-test or the Mann-Whitney $U$ test depending on normality. Data were shown as median and interquartile range. The correlations in the study were evaluated by calculation of Spearman's rho. P values lower than or equal to 0.05 were considered to show statistical significance.

\section{RESULTS}

A total of 63 patients with AA amyloidosis and 29 healthy controls were included in this study. The female/male distribution was $29(55 \%) / 34(45 \%)$ in the amyloidosis group, and $21(72 \%) / 8(28 \%)$ in control group. Statistical analysis revealed that sex distribution was different between groups $(p=0.019)$. However, the groups were similar in terms of age, SBP and DBP. Patients with amyloidosis had significantly lower BMI than controls $(p<0.001)$ (Table 1 ).

Urea, creatinine, phosphorus, CRP, ESR and PTH levels were significantly higher in amyloidosis patients compared to healthy controls ( $p<0.05$, for each comparison). In contrast, serum albumin, calcium levels and eGFR were significantly lower in amyloidosis patients compared to healthy controls $(p<0.001)$ (Table 1$)$.

There was no significant difference between patients and controls in terms of SF-A levels $(117.6 \pm 52.4 \mathrm{mmol} / \mathrm{L}$ vs. $119.9 \pm 23 \mathrm{mmol} / \mathrm{L}$, respectively) (Table 1 ). However, we determined that SF-A levels among patients with an eGFR value lower than $30 \mathrm{~mL} / \mathrm{min} / 1.73 \mathrm{~m}^{2}$ were significantly lower than the SF-A levels of those with eGFR values between 30-60 mL/min/1.73 $\mathrm{m}^{2}$ ( $p=0.011$ ).

Mean carotid IMT of those with AA amyloidosis $(0.8 \pm 0.4$ $\mathrm{mm}$ ) was significantly higher compared to the mean carotid IMT of the control group $(0.6 \pm 0.2 \mathrm{~mm})(p<0.001)$ (Table 1). There was no relationship between SF-A levels and carotid IMT in our patient group ( $r=0.074, p=0.565)$ (Figure 1). Similarly, there was also no correlation between SF-A levels and eGFR values ( $r=0.186, p=0.144)$.

In patients with $\mathrm{AA}$ amyloidosis, a positive correlation was determined between serum calcium and SF-A levels $(r=0.351, p=0.005)$ (Figure 2), and between serum albumin and SF-A levels $(r=0.271, p=0.031)$. In addition, there was a negative correlation between serum PTH levels and SF-A levels in the patient group $(r=0.325, p=0.019)$. The study showed no association between BMI, CRP, ESR, creatinine, urea, phosphate and SF-A values in the patient group.

\section{DISCUSSION}

Our study showed that the levels of ESR, CRP, urea, creatinine, phosphorus and $\mathrm{PTH}$ were increased in $\mathrm{AA}$

Table 1: Demographic characteristics and clinical measurements in amyloidosis and healthy control groups

\begin{tabular}{|c|c|c|c|}
\hline Parameter & Amyloidosis group & Control group & p value \\
\hline Age (years) & $51(24.0)$ & 48 (12.5) & 0.366 \\
\hline Gender (man/woman) & $29 / 34$ & $21 / 8$ & 0.019 \\
\hline BMI $\left(\mathrm{kg} / \mathrm{m}^{2}\right)$ & $24.8(3.8)$ & $28.1(6.98)$ & $<0.001$ \\
\hline $\mathrm{SBP}(\mathrm{mm} / \mathrm{Hg})$ & $120(30.0)$ & $120(17.5)$ & 0.609 \\
\hline $\mathrm{DBP}(\mathrm{mm} / \mathrm{Hg})$ & $80(15.0)$ & $80(12.5)$ & 0.434 \\
\hline Carotid IMT (mm) & $0.80(0.40)$ & $0.60(0.20)$ & $<0.001$ \\
\hline Fetuin-A (mmol/L) & $117.6(52.4)$ & $119.9(23.0)$ & 0.775 \\
\hline ESR (mm/hour) & $63(66.00)$ & $5.00(5.00)$ & $<0.001$ \\
\hline $\mathrm{CRP}(\mathrm{mg} / \mathrm{dL})$ & $1.32(2.24)$ & $0.33(0.49)$ & $<0.001$ \\
\hline Urea (mg/dL) & $51.0(53.00)$ & $25.0(9.0)$ & $<0.001$ \\
\hline Creatinine (mg/dL) & $1.50(1.77)$ & $0.68(0.20)$ & $<0.001$ \\
\hline eGFR (mL/min/1.73 m²) & $48.4(70.6)$ & $102.5(21.65)$ & $<0.001$ \\
\hline Albumin (g/dL) & $3.2(1.50)$ & $4.6(0.35)$ & $<0.001$ \\
\hline Calcium (ng/mL) & $8.7(1.0)$ & $9.5(0.65)$ & $<0.001$ \\
\hline Phosphate (ng/mL) & $3.8(1.20)$ & $3.4(0.75)$ & 0.001 \\
\hline PTH (pg/mL) & $71.3(109.2)$ & $46.9(25.03)$ & 0.044 \\
\hline
\end{tabular}

BMI: Body mass index, SBP: Systolic blood pressures, DBP: Diastolic blood pressures, IMT: Intima-media thickness, ESR: Erythrocyte sedimentation rate, CRP: C-reactive protein, eGFR: Estimated glomerular filtration rate, PTH: Parathyroid hormone 


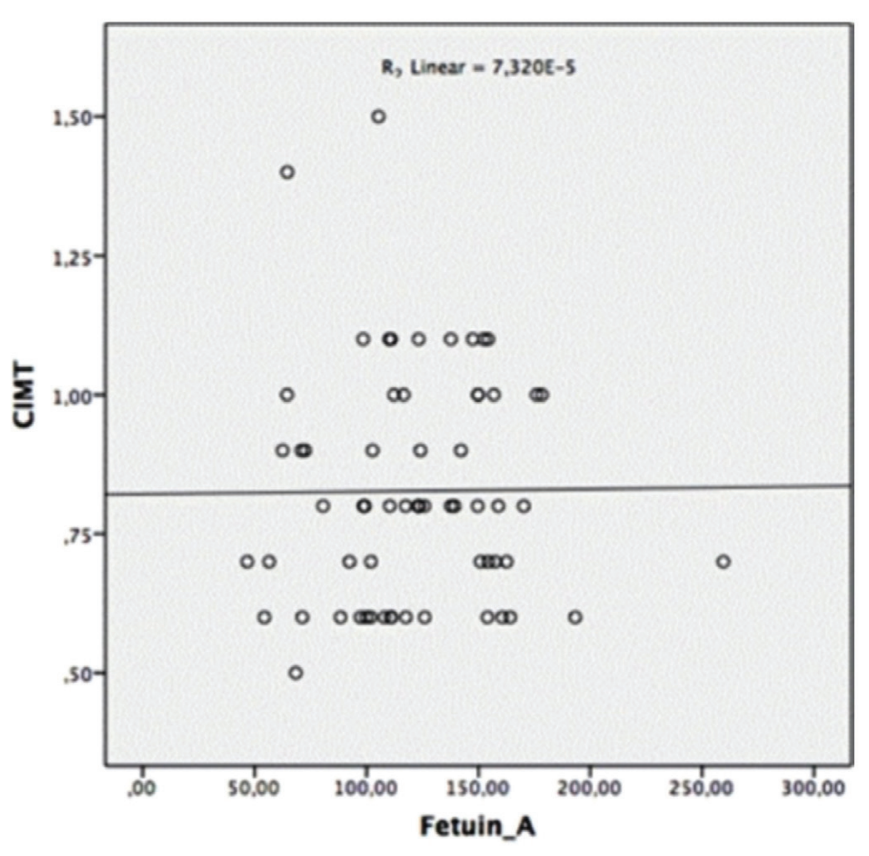

Figure 1: The relationship between serum fetuin - A levels and increased carotid intima-media thickness levels in the amyloidosis patients

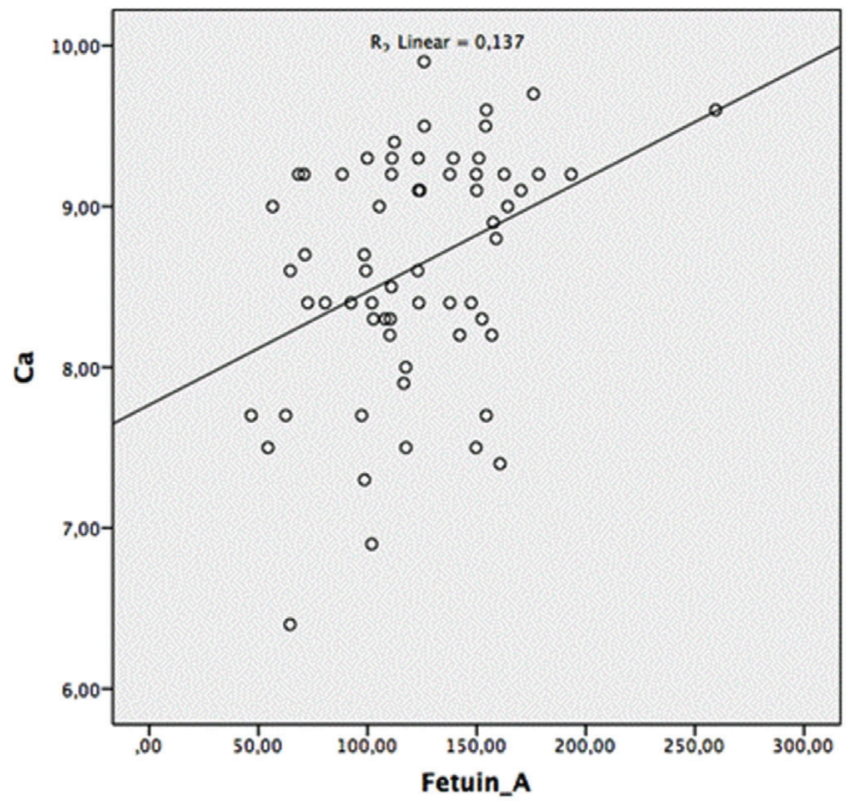

Figure 2: The relation between calcium levels and fetuin - A values in patients with amyloidosis

amyloidosis compared to controls; whereas serum albumin, calcium and eGFR were lower. In addition, we determined that the SF-A levels of AA amyloidosis patients with eGFR values under $30 \mathrm{~mL} / \mathrm{min} / 1.73 \mathrm{~m}^{2}$ were lower compared to the SF-A levels of AA amyloidosis patients whose eGFR values were between $30-60 \mathrm{~mL} / \mathrm{min} / 1.73 \mathrm{~m}^{2}$. Furthermore, we found that carotid IMT was increased patients with AA amyloidosis compared to controls. Lastly, in regard to correlation analyses, we found positive correlations between SF-A and the levels of serum calcium and serum albumin. Additionally, we also showed the existence of a negative correlation between serum PTH levels and SF-A levels.

To our knowledge, this is the first study to investigate the association between SF-A levels and different parameters affecting mineralization dynamics and subclinical atherosclerosis in AA amyloidosis patients. We found no association between higher levels of SF-A and AA amyloidosis.

A previous study investigated the vascular calcification process in patients with chronic renal failure. This study concluded that chronic renal failure is associated with the loss of inhibition of mineralization as well as an unbalanced calcium and phosphate homeostasis. The same study also indicated that SF-A had a role in the vascular calcification in recipients of hemodialysis (14).

Various studies have focused on SF-A levels in type 2 diabetes mellitus and chronic kidney disease (CKD). Several of these studies have shown that there is a strong association between SF-A levels and the risk for diabetes (15-19). Furthermore, SF-A levels were reportedly lower in patients with type 2 diabetes (20). While Sujana et al. (21) determined that higher SF-A levels were associated with incident type 2 diabetes in both genders, regardless of the presence of subclinical inflammation, the levels of adiponectin, and fat content of the liver. Despite many other studies indicating a role for SF-A in diabetes, a recent systematic review found that the relationship between diabetes and SF-A was only evident in females; the authors also concluded that further studies were required to understand the underlying cause of this relationship (22).

Siraz et al. showed that patients with non-alcoholic fatty liver disease (NAFLD) had elevated SF-A levels. They identified a SF-A cut-off to predict NAFLD presence; however, while specificity was quite high (97\%), sensitivity was as low as $47 \%$. The authors also suggested that SF-A was a reliable parameter for the prediction of complications in patients with type 1 diabetes mellitus (23). These findings show that SF-A may have a role in various diseases due to its role in metabolic pathways.

In a study which investigated basal ganglia calcification, by Demiryurek et al. (24), it was determined that SF-A levels 
were lower in patients with basal ganglia calcification compared to subjects without calcification. They suggested that SF-A level may be used as a biomarker in the prediction of basal ganglia calcification (24).

A few studies have investigated whether there exists a relationship between carotid IMT and SF-A levels. In essential hypertension patients, higher SF-A levels were associated with increased IMT, independent of oxidative stress and renal function (25). Liang et al. (26) showed a negative correlation between SF-A level and carotid IMT. They also concluded that lower SF-A level was a risk factor for carotid artery calcification in patients with CKD. In the current study, we found no relationship between carotid IMT values and the levels of SF-A in our group of patients with AA amyloidosis ( $r=0.074, p=0.565)$, (Figure 1 ). Furthermore, our study showed that the carotid IMT of patients with AA amyloidosis were statistically higher than that of controls $(p<0.001)$ (Table 1$)$.

There are also studies in which SF-A levels were investigated in patients with CKD. Caglar et al. (27) found that SF-A concentrations were decreased at all stages of CKD except stage 1. They also showed that endothelial dysfunction was associated with SF-A, regardless of CKD. Hence, they concluded that SF-A may be a factor that contributes to the development of endothelial dysfunction in CKD patients (28). In contrast, Alderson et al. (29) reported that there was no clear association between SF-A levels and any risk factors associated with renal replacement therapy, cardiovascular events and death in non-dialysis patients with stage 3-5 CKD.

Dervisoglu et al. (30) found that higher serum SF-A levels were associated with lower interleukin (IL)- $1 \beta$, IL- 6 and tumor necrosis factor- $\alpha$ levels in their group of 64 patients with CKD. They concluded that the inverse relationship between SF-A and cytokine levels was associated with the down-regulation of SF-A expression during inflammation. In the present study, we showed that CRP and ESR levels were higher in amyloidosis patients compared to controls $(p<0.05)$. However, no correlations were found between CRP, ESR and SF-A levels in our patients ( $p>0.05$ ).

In a study by Zhan et al. (31), it was determined that SF-A levels decreased in parallel with the decrease in eGFR levels of CKD patients. Similarly, our study showed that SF-A levels were lower in patients with eGFR values below $30 \mathrm{~mL} / \mathrm{min} / 1.73 \mathrm{~m}^{2}$ compared to those with eGFR values between $30-60 \mathrm{~mL} / \mathrm{min} / 1.73 \mathrm{~m}^{2}(p=0.011)$. However, we found no association between SF-A levels and eGFR values in $A A$ amyloidosis patients ( $r=0.186, p=0.144)$.

A study by Shouman et al. (32), which investigated SF-A levels in hemodialysis patients, showed that pre-dialysis SF-A levels were higher in pediatric hemodialysis patients compared to healthy subjects. Furthermore, they showed a significant decrease in SF-A levels after a single session of hemodialysis (33). In another study by Kirkpantur et al. (34), SF-A levels were reported to be associated with coronary artery calcification and the bone mineral density of recipients of maintenance hemodialysis. On the other hand, Lin et al. (35) found that increased calcium, decreased PTH and albumin levels were associated with the decrease in SF-A levels observed in hemodialysis patients. Similarly, the current study showed a positive correlation between calcium levels and SF-A levels ( $r=0.351, p=0.005)$, and a negative correlation between $\mathrm{PTH}$ levels and SF-A levels in patients with AA amyloidosis ( $r=0.325, p=0.019)$.

We believe that the findings of our study contribute to the literature in terms of clarifying the role of SF-A in AA amyloidosis.

Our findings should be interpreted in the context of several limitations. We acknowledge that the small number of AA amyloidosis patients in our study is a limitation. Further, all subjects were from a single center; therefore, it is apparent that future multi-centered studies with a higher number of patients are required to confirm our results. Finally, this study is cross-sectional in design, and did not employ prospective follow-up. As such, the relationships shown in this study should not be considered to show causality.

\section{CONCLUSION}

Our study showed that there were no differences between patients with $A A$ amyloidosis and healthy controls in terms of SF-A levels, and no correlations were found between carotid IMT and SF-A levels in patients with AA amyloidosis. However, higher SF-A levels were associated with higher calcium and albumin levels, while SF-A levels were also negatively correlated with PTH levels. In addition, SF-A levels of AA amyloidosis patients with eGFR $<30 \mathrm{~mL} / \mathrm{min} / 1.73 \mathrm{~m}^{2}$ were found to be lower than that of patients with eGFR values between $30-60 \mathrm{~mL} / \mathrm{min} / 1.73$ $\mathrm{m}^{2}$. Additional studies are required to investigate the relationship between SF-A levels and carotid IMT, and to clarify the possible role of SF-A in AA amyloidosis. 


\section{Ethics}

Ethics Committee Approval: The study was approved by İstanbul Medeniyet University Göztepe Training and Research Hospital Clinical Research Ethics Committee on April 10, 2018 (protocol number: 2013-KAEK-64).

Informed Consent: Informed consents were taken from all of the subjects.

Peer-review: Externally peer-reviewed.

\section{Authorship Contributions}

Concept: A.B., S.A.E., Design: A.B., S.A.E., Data Collection or Processing: A.B., S.A.E., Analysis or Interpretation: A.B., S.A.E., Literature Search: A.B., S.A.E., Writing: A.B., S.A.E.

Conflict of Interest: No conflict of interest was declared by the authors.

Financial Disclosure: The authors declared that this study received no financial support.

\section{REFERENCES}

1. Ueno T, Takeda K, Nagata M. Remission of proteinuria and preservation of renal function in patients with renal AA amyloidosis secondary to rheumatoid arthritis. Nephrol Dial Transplant 2012;27:633-9.

2. Laurent S, Cockcroft J, Van Bortel L, Boutouyrie P, Giannattasio C, Hayoz D, et al. Expert consensus document on arterial stiffness: methodological issues and clinical applications. Eur Heart J 2006;27:2588-605.

3. Boutouyrie P, Tropeano Al, Asmar R, Gautier I, Benetos A, Lacolley P, et al. Aortic stiffness is an independent predictor of primary coronary events in hypertensive patients: a longitudinal study. Hypertension 2002;39:10-5.

4. Lorenz MW, Markus HS, Bots ML, Rosvall M, Sitzer M. Prediction of clinical cardiovascular events with carotid intima-media thickness: a systematic review and meta-analysis. Circulation 2007;115:459-67.

5. Salonen JT, Salonen R. Ultrasound B-mode imaging in observational studies of atherosclerotic progression. Circulation 1993;87(3 Suppl):II56-65.

6. Bots ML, Hoes AW, Koudstaal PJ, Hofman A, Grobbee DE. Common carotid intima-media thickness and risk of stroke and myocardial infarction: the Rotterdam Study. Circulation 1997;96:1432-7.

7. Jahnen-Dechent W, Heiss A, Schafer C, Ketteler M. Fetuin-A regulation of calcified matrix metabolism. Circ Res 2011;108:1494-509.

8. Schafer C, Heiss A, Schwarz A, Westenfeld R, Ketteler M, Floege J, et al. The serum protein alpha 2-Heremans-Schmid glycoprotein/ fetuin-A is a systemically acting inhibitor of ectopic calcification. J Clin Invest 2003;112:357-66.

9. Wang $H$, Sama AE. Anti-inflammatory role of fetuin-A in injury and infection. Curr Mol Med 2012;12:625-33.

10. Roos $M$, von Eynatten $M$, Heemann $U$, Rothenbacher $D$, Brenner $H$, Breitling LP. Serum fetuin-A, cardiovascular risk factors, and six-year follow-up outcome in patients with coronary heart disease. Am J Cardiol 2010;105:1666-72.
11. Ix JH, Chertow GM, Shlipak MG, Brandenburg VM, Ketteler M, Whooley MA. Fetuin-A and kidney function in persons with coronary artery disease--data from the Heart and Soul Study. Nephrol Dial Transplant 2006;21:2144-51.

12. Levey AS, Stevens LA, Schmid CH, Zhang YL, Castro AF, 3rd, Feldman $\mathrm{HI}$, et al. A new equation to estimate glomerular filtration rate. Ann Intern Med 2009;150:604-12.

13. Pignoli P, Tremoli E, Poli A, Oreste P, Paoletti R. Intimal plus medial thickness of the arterial wall: a direct measurement with ultrasound imaging. Circulation 1986;74:1399-406.

14. Roos M, Lutz J, Salmhofer $H$, Luppa $P$, Knauss A, Braun $S$, et al. Relation between plasma fibroblast growth factor-23, serum fetuin- $A$ levels and coronary artery calcification evaluated by multislice computed tomography in patients with normal kidney function. Clin Endocrinol (0xf) 2008;68:660-5.

15. Ix JH, Biggs ML, Mukamal KJ, Kizer JR, Zieman SJ, Siscovick DS, et al. Association of fetuin-a with incident diabetes mellitus in communityliving older adults: the cardiovascular health study. Circulation 2012;125:2316-22.

16. Ix JH, Wassel CL, Kanaya AM, Vittinghoff E, Johnson KC, Koster A, et al. Fetuin-A and incident diabetes mellitus in older persons. JAMA 2008;300:182-8.

17. Stefan N, Fritsche A, Weikert C, Boeing $H$, Joost $H G$, Haring $H U$, et al. Plasma fetuin-A levels and the risk of type 2 diabetes. Diabetes 2008;57:2762-7.

18. Sun $\mathrm{Q}$, Cornelis $M C$, Manson JE, Hu FB. Plasma levels of fetuin-A and hepatic enzymes and risk of type 2 diabetes in women in the U.S. Diabetes 2013;62:49-55.

19. Aroner SA, Mukamal KJ, St-Jules DE, Budoff MJ, Katz R, Criqui $\mathrm{MH}$, et al. Fetuin-A and Risk of Diabetes Independent of Liver Fat Content: The Multi-Ethnic Study of Atherosclerosis. Am J Epidemiol 2017;185:54-64.

20. Eleftheriadou I, Grigoropoulou P, Kokkinos A, Mourouzis I, Perrea $D$, Katsilambros $N$, et al. Association of plasma fetuin-a levels with peripheral arterial disease and lower extremity arterial calcification in subjects with type 2 diabetes mellitus. J Diabetes Complications 2017;31:599-604.

21. Sujana C, Huth C, Zierer A, Meesters S, Sudduth-Klinger J, Koenig $W$, et al. Association of fetuin-A with incident type 2 diabetes: results from the MONICA/KORA Augsburg study and a systematic metaanalysis. Eur J Endocrinol 2018;178:389-98.

22. Guo VY, Cao B, Cai $C$, Cheng KK, Cheung BMY. Fetuin-A levels and risk of type 2 diabetes mellitus: a systematic review and meta-analysis. Acta Diabetol 2018;55:87-98.

23. Siraz UG, Dogan M, Hatipoglu N, Muhtaroglu S, Kurtoglu S. Can Fetuin-A Be a Marker for Insulin Resistance and Poor Glycemic Control in Children with Type 1 Diabetes Mellitus? J Clin Res Pediatr Endocrinol 2017;9:293-9.

24. Demiryurek BE, Gundogdu AA. Serum Fetuin-A Levels in Patients with Bilateral Basal Ganglia Calcification. Neurosci Lett 2018;666:148-52.

25. Guarneri M, Geraci C, Incalcaterra F, Arsena R, Mule G, Vaccaro F, et al. Subclinical atherosclerosis and fetuin-A plasma levels in essential hypertensive patients. Hypertens Res 2013;36:129-33.

26. Liang J, Wang Z, Liu G, Zhan J, Jiang L, Jiang Z. Association of dialysate calcium concentration with fetuin A level and carotid intima-media thickness in peritoneal dialysis patients. Ren Fail 2014;36:65-8. 
27. Caglar K, Yilmaz MI, Saglam M, Cakir E, Kilic S, Sonmez A, et al. Serum fetuin-a concentration and endothelial dysfunction in chronic kidney disease. Nephron Clin Pract 2008;108:233-40.

28. Caglar K, Yilmaz MI, Saglam M, Cakir E, Kilic S, Eyileten T, et al. Endothelial dysfunction and fetuin A levels before and after kidney transplantation. Transplantation 2007;83:392-7.

29. Alderson HV, Ritchie JP, Middleton R, Larsson A, Larsson TE, Kalra PA. FGF-23 and Osteoprotegerin but not Fetuin-A are associated with death and enhance risk prediction in non-dialysis chronic kidney disease stages 3-5. Nephrology 2016;21:566-73.

30. Dervisoglu E, Kir HM, Kalender B, Caglayan C, Eraldemir C. Serum fetuin--a concentrations are inversely related to cytokine concentrations in patients with chronic renal failure. Cytokine 2008;44:323-7.

31. Zhan J, Liang J, Wang Z. [Relations of fetuin-A with estimated glomerular filtration rate and carotid artery calcification in patients with chronic kidney disease]. Nan Fang Yi Ke Da Xue Xue Bao 2013;33:1689-91.

32. Shouman MG, Ismail NA, Badr A, Abdelrahman SM, Ragab S, Farouk $H$. Fetuin-A and Ghrelin Levels in Children with End Stage Renal Disease and the Effect of a Single Hemodialysis Session on Them. Open Access Maced J Med Sci 2015;3:391-6.

33. Shouman MG, Ismail NA, Badr A, Abdelrahman SM, Ragab S, Farouk $H$. Fetuin-A and Ghrelin Levels in Children with End Stage Renal Disease and the Effect of a Single Hemodialysis Session on Them. Open Access Maced J Med Sci 2015;3:391-6.

34. Kirkpantur A, Altun B, Hazirolan T, Akata D, Arici M, Kirazli S, et al. Association among serum fetuin-A level, coronary artery calcification, and bone mineral densitometry in maintenance hemodialysis patients. Artif Organs 2009;33:844-54.

35. Lin $\mathrm{H}-\mathrm{H}$, Liou $\mathrm{H}-\mathrm{H}$, Wu M-S, Huang $\mathrm{C}-\mathrm{C}$. Factors associated with serum fetuin-A concentrations after long-term use of different phosphate binders in hemodialysis patients. BMC Nephrol 2016;17:33. 